\title{
Purification and Properties of Leucine Aminopeptidase II from Aspergillus oryzae
}

\author{
Tadanobu Nakadal, Seiichi Nasuno and Nobuyoshi IGuchI \\ Noda Institute for Scientific Research, Noda-shi, Chiba-ken \\ Received July 27, 1972
}

\begin{abstract}
Aminopeptidase II from Aspergillus oryzae 460 was purified from the rivanol precipitable fraction. The purified enzyme was homogeneous in polyacrylamide gel disc electrophoresis. Its optimum $\mathrm{pH}$ is at $\mathrm{pH} 8.0$ for L-leucyl-glycyl-glycine and L-leucyl- $\beta$-naphthylamide. The enzyme was inhibited by metal chelating agents and S-S dissociating agents, but not inhibited by SH reagents. The molecular weight of the enzyme was estimated to be about 61,000 by gel filtration. The enzyme was most active toward oligopeptides of amino terminal leucine, indicating that it was a kind of leucine aminopeptidase. Thus, the enzyme was proposed to be called leucine aminopeptidase II of Asp. oryzae 460 .
\end{abstract}

Of the proteolytic enzymes of Aspergillus oryzae $^{11}$ and Asp. sojae ${ }^{2)}$ exopeptidases were found to be main enzymes to liberate free amino acids from soybean protein and some enzymatic properties of purified acid carboxypeptidase $\mathrm{I}^{3}, \mathrm{II}^{3},{ }^{4} \mathrm{III}^{5}$ and leucine aminopeptidase $I^{\hat{b})}$ were reported in a series of previous papers.

This paper deals with purification and some properties of leucine aminopeptidase II as a part of the systematic purification of peptidases from Asp. oryzae 460 (FERM-P No. 1149). ${ }^{7}$

\section{MATERIALS AND METHODS}

Aminopeptidase activity was determined with LeuGly-Gly by the same method as reported in the previous papers. ${ }^{3,4}$ In some cases Leu- $\beta$-naphthylamide was used as the substrate and activity was determined by the same method as reported in previous papers. ${ }^{6,8}$ All the other experimental methods were described in the previous paper. ${ }^{3 \prime}$

\section{RESULTS}

\section{Gel filtration on Sephadex G-100}

The fractions of aminopeptidase II from DEAE-cellulose chromatography reported previously ${ }^{* 6)}$ were concentrated to $3 \mathrm{ml}$ by a

\footnotetext{
* See the previous paper ${ }^{6}$ for abbreviations used in this paper.
}

Diaflo UM-1 (Amicon Co.) and applied to a column $(2.3 \times 150 \mathrm{~cm})$ of Sephadex G-100 equilibrated with $0.1 \mathrm{M}$ acetate buffer at $\mathrm{pH}$ 6.5. Elution was performed with the same buffer and $15 \mathrm{ml}$ each of fractions was collected. Active fractions of aminopeptidase were combined, pooled and concentrated to $3 \mathrm{ml}$ by a Diaflo UM-1.

\section{Gel filtration on Sephadex $G-200$}

The concentrated solution was applied to a column $(2.8 \times 118 \mathrm{~cm})$ of Sephadex G-200 equilibrated with $0.1 \mathrm{M}$ acetate buffer at $\mathrm{pH}$ 6.5. Elution was performed with the same buffer and $15 \mathrm{ml}$ each of fractions was collected. Active fractions (aminopeptidase II) were collected and desalted by dialysis against distilled water.

\section{Column chromatography on DEAE-Sephadex $A-50$}

The above enzyme preparation of aminopeptidase II after dialysis was adjusted to $\mathrm{pH}$ 7.0 and charged on a column $(3 \times 30 \mathrm{~cm})$ of DEAE-Sephadex A-50 equilibrated with 0.01 M phosphate buffer at $\mathrm{pH}$ 6.0. After being washed with $0.01 \mathrm{M}$ phosphate buffer ( $\mathrm{pH} 7.0$ ), the adsorbed protein was eluted by a linear gradient of $\mathrm{NaCl}$ concentration. A reservoir was filled with 2 liters of $0.4 \mathrm{M} \mathrm{NaCl}$ in the 


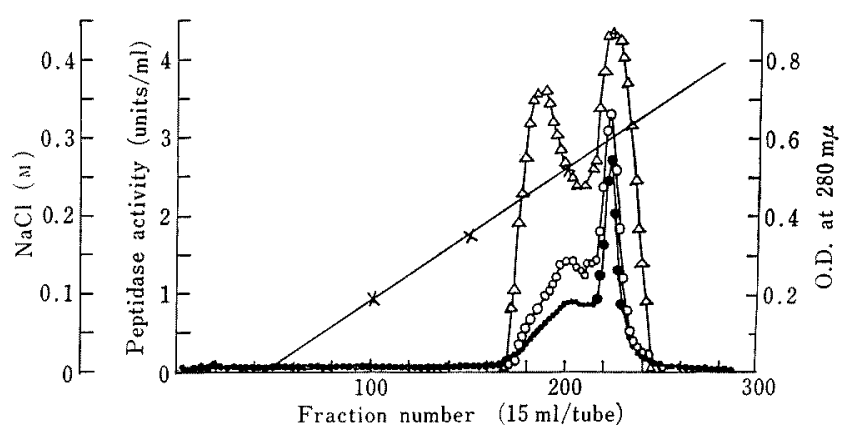

FIG. 1. Chromatography of Aminopeptidase II on DEAE-Sephadex A-50. See the text for experimental details.

$0-0$ : peptidase activity for Leu-Gly-Gly. $\Delta-\Delta$, peptidase activity for Cbz-Glu-Tyr, units $/ \mathrm{ml} \times 10^{-2} ;-$ O.D. at $280 \mathrm{~m} \mu ; \times-\times, \mathrm{NaCl}$ concentration.

same buffer and a mixing chamber contained 2 liters of the same buffer. Figure 1 illustrates an elution pattern of aminopeptidase II. Fractions 172 to 200 were collected, adjusted to $\mathrm{pH} 5.5$ and tentatively named acid carboxypeptidase IV. Fractions 214 to 236 were combined and used for the preparation of purified aminopeptidase II.

\section{Gel filtration on Sephadex G-200}

Aminopeptidase II fraction obtained by DEAE-Sephadex A-50 chromatography was concentrated to $3 \mathrm{ml}$ by a Diaflo UM-1 and applied to a column $(2.8 \times 118 \mathrm{~cm})$ of Sephadex G-200 equilibrated with $0.1 \mathrm{M}$ acetate buffer at $\mathrm{pH}$ 6.5. Figure 2 shows a typical elution pattern of aminopeptidase II. Pooled fractions of 27 to 38 were frozen and stored at

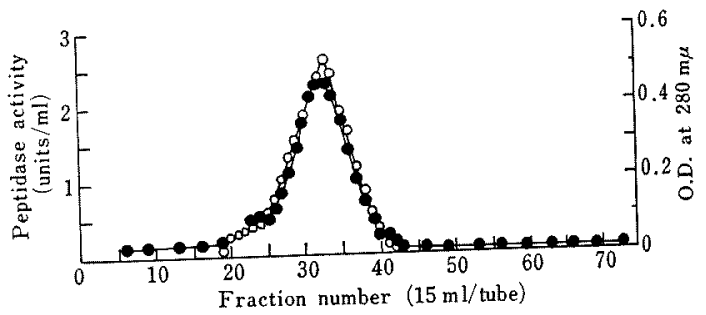

FIG. 2. Gel Filtration of Aminopeptidase II through Sephadex G-200.

See the text for experimental details.

$\bigcirc-O$, peptidase activity for Leu-Gly-Gly;

O.D. at $280 \mathrm{~m} \mu$.

$-15^{\circ} \mathrm{C}$.

A summary of the purification procedure is shown in Table I.

Determination of molecular weight by gel filtration

Table I. Purification of Leucine Aminopeptidase II

\begin{tabular}{lrrrr}
\multicolumn{1}{c}{ Procedure } & $\begin{array}{c}\text { Total } \\
\text { volume } \\
\text { ml }\end{array}$ & $\begin{array}{c}\text { Total } \\
\text { activity } \\
\text { Units }^{a \mid}\end{array}$ & $\begin{array}{c}\text { Specific } \\
\text { activity } \\
\text { U/mg } \\
\text { protein }^{a \mid}\end{array}$ & $\begin{array}{c}\text { Yield } \\
\%\end{array}$ \\
\hline Crude enzyme solution & 10,100 & 5910 & 0.181 & 100 \\
Batchwise treatment with Amberlite IRC-50 & 10,200 & 5740 & 0.490 & 97.3 \\
Fractionation with ammonium sulfate & 235 & 3280 & 0.545 & 55.5 \\
Rivanol precipitation & 104 & 2190 & 1.44 & 38.2 \\
DEAE-cellulose chromatography & 810 & 1870 & 2.72 & 31.7 \\
Gel filtration on Sephadex G-100 & 66 & 974 & 3.24 & 16.5 \\
Gel filtration on Sephadex G-200 & 220 & 587 & 3.02 & 9.94 \\
DEAE-Sephadex A-50 chromatography & 330 & 468 & 4.70 & 7.93 \\
Gel filtration on Sephadex G-200 & 166 & 262 & 4.54 & 4.43 \\
\hline
\end{tabular}

a) Peptidase activity was determined with Leu-Gly-Gly. 


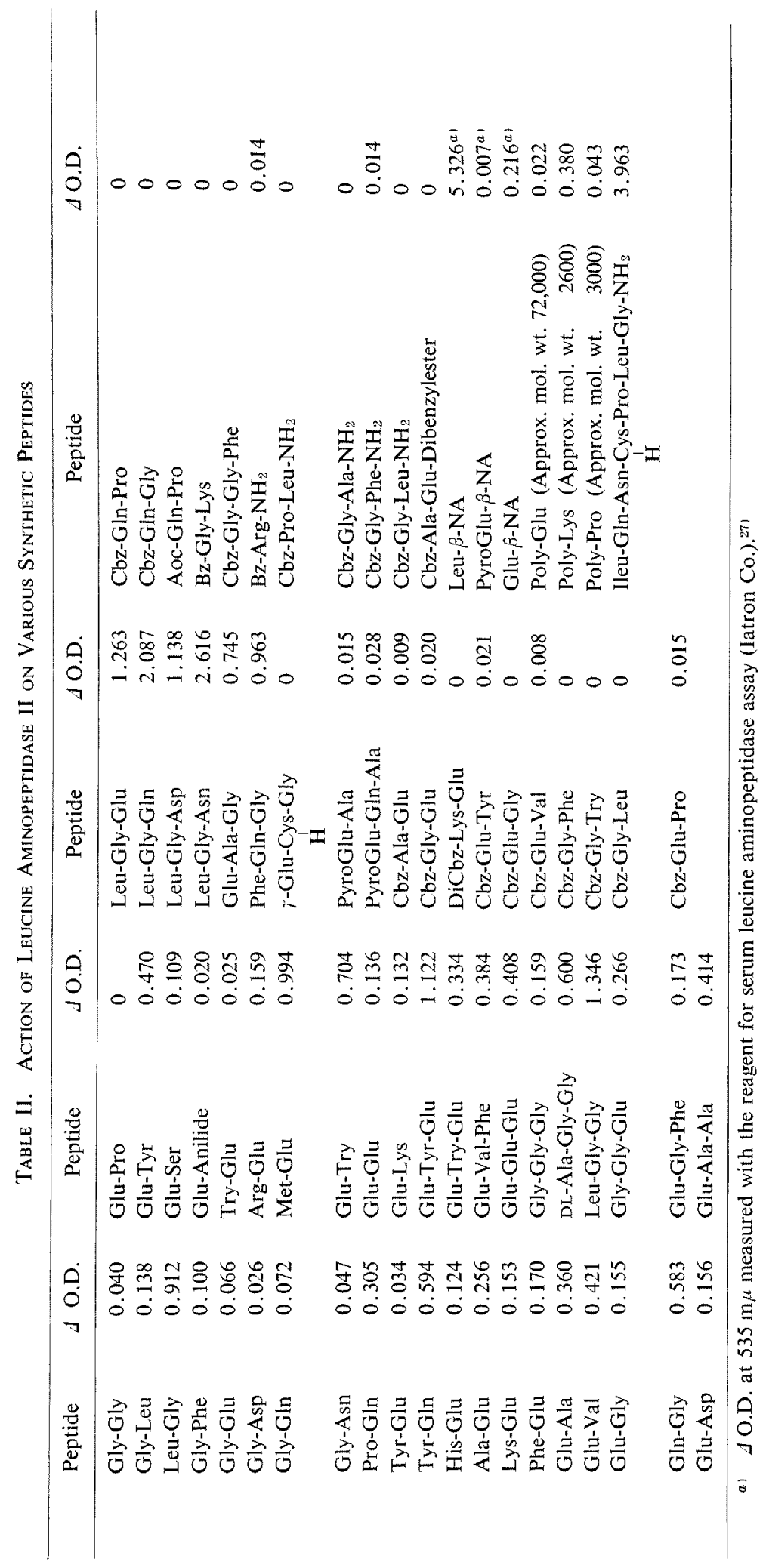




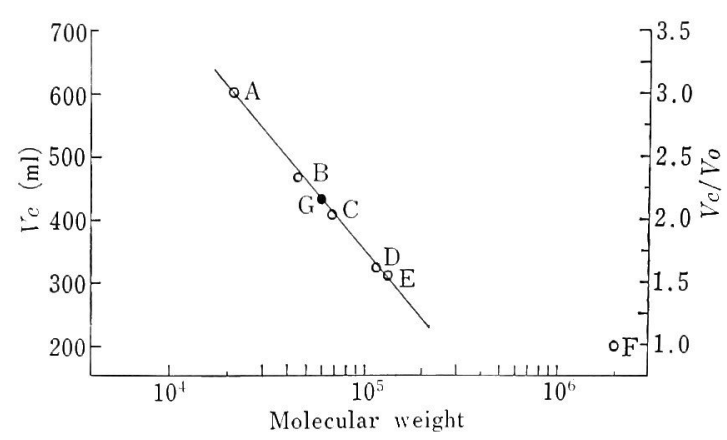

Fig. 3. Plots of Elution Volume, Ve, on a Sephadex G-200 Column against Logarithms of Molecular Weights of Proteins.

See the previous paper $^{3}$ for experimental details. A, trypsin, B, ovalbumin; C, human albumin; D, intestinal alkaline phosphatase; $\mathrm{E}$, human albumin dimer; F, blue dextran; G, aminopeptidase II.

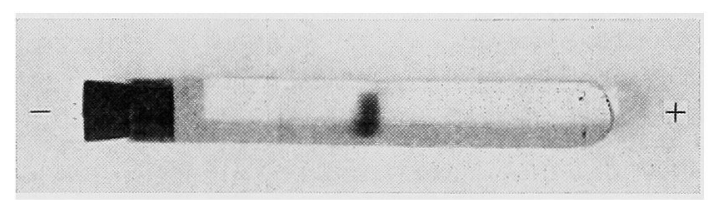

FIG. 4. Polyacrylamide Gel Electrophoresis of Purified Aminopeptidase II from Aspergillus oryzae at $\mathrm{pH} 9.4$ for $30 \mathrm{~min}$.

The electrophoresis was operated in the cold $\left(4^{\circ} \mathrm{C}\right)$ for $30 \mathrm{~min}$ at $4 \mathrm{~mA}$ per gel column. ${ }^{28}$ !

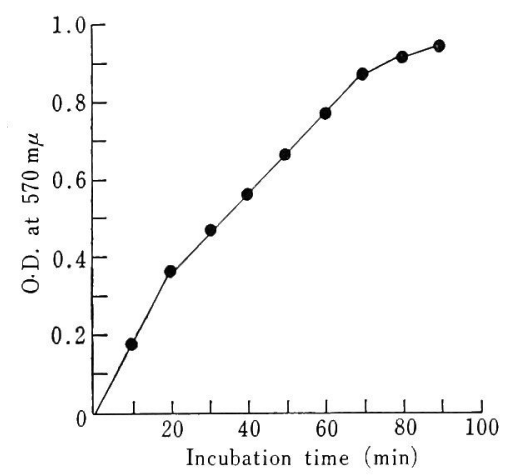

FIG. 5. Time Course of Hydrolysis of Leu-Gly-Gly by Aminopeptidase II.

Peptidase activity was assayed at various time at $30^{\circ} \mathrm{C}$ with purified enzyme $(3.48 \mu \mathrm{g}) . \quad 0.05 \mathrm{M}$ Tris- $\mathrm{HCl}$ buffer ( $\mathrm{pH}$ 8.0) was used.

Figure 3 shows the plots of elution volume (Ve) through a Sephadex G-200 (pH 5.5) column against logarithms of molecular weights of standard proteins and aminopeptidase II. The molecular weight of aminopeptidase II determined by this method was calculated to be 61,000 .

\section{Disc electrophoresis}

To check the purity of the enzyme, the final enzyme preparation was submitted to polyacrylamide gel disc electrophoresis at $\mathrm{pH}$ 9.4. A single protein band corresponding to aminopeptidase II was found as shown in Fig. 4.

\section{Action on various peptides}

The hydrolytic action of the aminopeptidase II on various peptides was examined by the ninhydrin method. To $0.5 \mathrm{ml}$ of enzyme solution (348 $\mu \mathrm{g}$ protein $/ \mathrm{ml}$ ) buffered to $\mathrm{pH}$ 6.5 with $0.1 \mathrm{M}$ acetate buffer was added $0.5 \mathrm{ml}$ each of $5 \times 10^{-4} \mathrm{M}$ solution for di- and tripeptides and each $10^{-3} \mathrm{M}$ solution for other peptides. After incubation at $30^{\circ} \mathrm{C}$ for $30 \mathrm{~min}$ in the presence of $10^{-3} \mathrm{M} \mathrm{CoSO}_{4}$, the amino acid liberated was measured by ninhydrin method. The results are summarized in Table II. The aminopeptidase II preferentially hydrolyzed the oligopeptides that possess leucine at the $\mathrm{N}$-terminal, liberating amino terminal amino acid. Thus, we propose to call this enzyme leucine aminopeptidase II.

\section{Time course of hydrolysis of Leu-Gly-Gly}

The time course of hydrolysis of Leu-Gly-Gly by the leucine aminopeptidase II gave straight line to O.D. 0.4 (Fig. 5).

\section{Effect of $\mathrm{pH}$ on leucine aminopeptidase II}

The effect of $\mathrm{pH}$ on leucine aminopeptidase II activity was studied with some peptides in acetate ( $\mathrm{pH} 3.0$ to 6.0 ), tris- $\mathrm{HCl}(\mathrm{pH} 6.5$ to 9.0) and phosphate (pH 6.0 to 8.0 ) buffers. Purified leucine aminopeptidase II was most active at $\mathrm{pH} 8.0$ toward both Leu-Gly-Gly and Leu- $\beta$-napthylamide, at $\mathrm{pH} 5.0$ for $\alpha$-GluTyr-Glu and at pH 5.5 for Met-Glu (Fig. 6) in the presence of $10^{-3} \mathrm{M} \mathrm{CoSO}_{4}$. The ratio of enzyme activity in units for Leu-Gly-Gly $(\mathrm{pH} 8.0)$ to Leu- $\beta$-naphthylamide ( $\mathrm{pH} 8.0$ ), $\alpha$-Glu-Tyr-Glu (pH 5.0) and Met-Glu (pH 5.5) was $92.9: 43.8: 18.4: 1$. The enzyme was found to be stable in the $\mathrm{pH}$ range of 5.5 to 9 


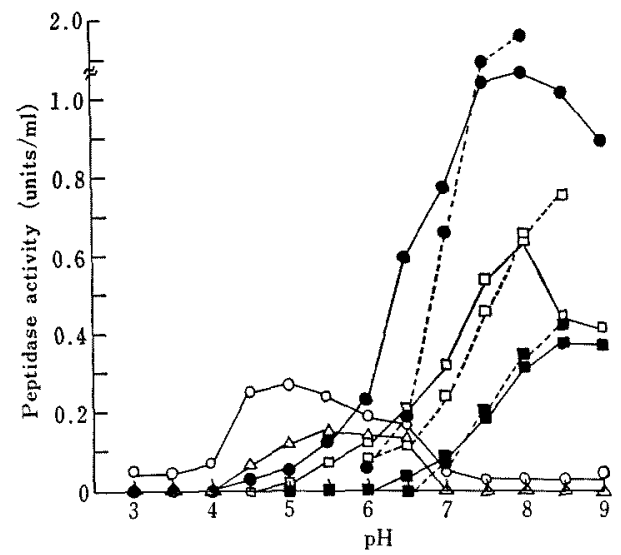

Fig. 6. Effect of pH on Activity of Leucine Aminopeptidase II.

-- Leu-Gly-Gly; O-O, $\alpha$-Glu-Tyr-Glu; $\Delta-\Delta$, Met-Glu (units/ml $\left.\times 10^{-1}\right) ; \square-\square$, Leu- $\beta-\mathrm{NA} ; \mathbf{\square}-\mathbf{n}$, Leu- $\beta$-NA $\quad\left(10^{-3} \mathrm{M} \quad \mathrm{CoSO}_{4}\right.$ was omitted. $)$-.-., phosphate buffer ( $\mathrm{pH} 6.0$ to 8.5 ); - - acetate buffer (pH 3.0 to 6.0 ) and Tris-HCl buffer (pH 6.5 to 9.0 ). Peptidase activity was assayed after $10 \mathrm{~min}$ at $30^{\circ} \mathrm{C}$ with purified enzyme $(348 \mu \mathrm{g} / \mathrm{ml})$.

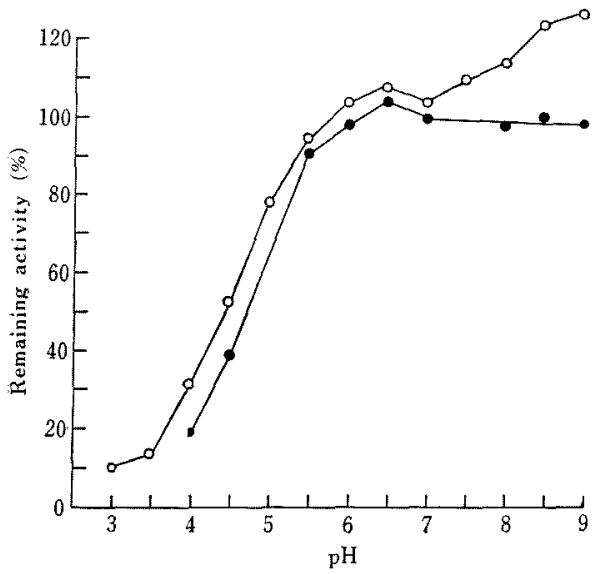

FIG. 7. pH Stability of Leucine Aminopeptidase II.

-- Leu-Gly-Gly (pH 8.0); O-O, Leu- $\beta$-NA (pH 8.0). To $25 \mu 1$ of $0.25 \mathrm{~m}$ buffer of various $\mathrm{pH}$ values, $100 \mu \mathrm{l}$ of purified and dialyzed enzyme solution was added, and the mixture was incubated at $37^{\circ} \mathrm{C}$ for $2 \mathrm{hr}$. $0.05 \mathrm{M}$ acetate buffer ( $\mathrm{pH} \mathrm{3.0}$ to 6.0) and $0.05 \mathrm{M}$ Tris- $\mathrm{HCl}$ buffer (pH 6.5 to 9.0 ) were used.

during preincubation at $37^{\circ} \mathrm{C}$ for $2 \mathrm{hr}$. Preincubation at $37^{\circ} \mathrm{C}$ at $\mathrm{pH} 7.5$ to 9.0 for $2 \mathrm{hr}$ resulted in roughly 10 to $20 \%$ increase of arylamidase activity measured at $30^{\circ} \mathrm{C}$ (Fig. 7).

Effect of temperature on leucine aminopeptidase II

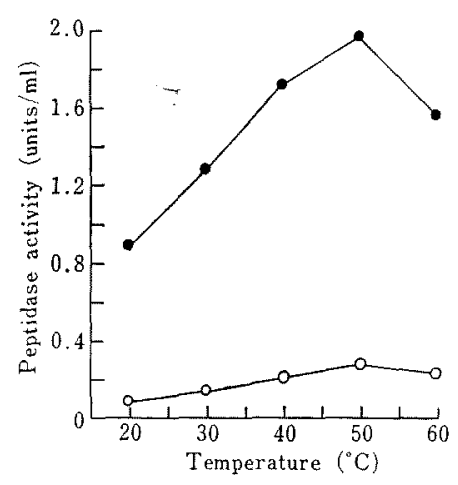

FIG. 8. Effect of Temperature on Activity of Leucine Aminopeptidase II.

- - Lell-Gly-Gly (pH 8.0); O-O, Leu- $\beta-N A$ (pH 8.0).

The incubation mixtures contained $0.05 \mathrm{M}$ Tris- $\mathrm{HCl}$ buffer (pH 8.0), $2.5 \times 10^{-4} \mathrm{M}$ Leu-Gly-Gly or $0.02 \%$ Leu- $\beta$-naphthylamide and the purified enzyme. Enzyme activity was assayed after $10 \mathrm{~min}$ at various temperatures.

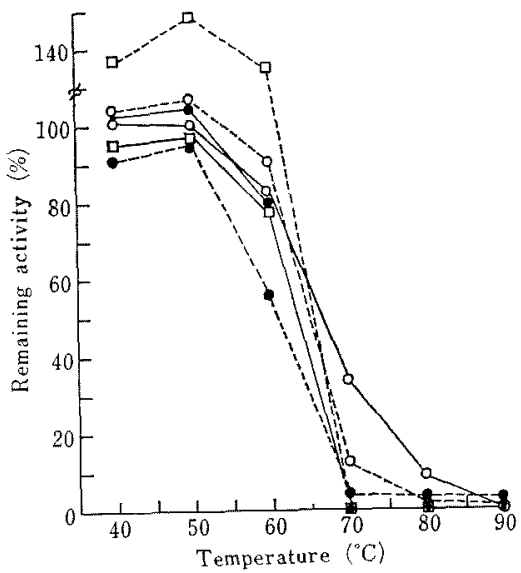

FIG. 9. Heat Stability of Leucine Aminopeptidase II.

- control; $\mathrm{O}-\mathrm{O}$, in the presence of $10^{-2} \mathrm{M}$ $\mathrm{Ca}\left(\mathrm{CH}_{3} \mathrm{COO}\right)_{2} ; \square-\square$, in the presence of $10^{-2} \mathrm{M}$ $\mathrm{CoSO}_{4}$. — - Leu-Gly-Gly (pH8.0); ----, Leu- $\beta$-NA (pH 8.0). The incubation mixtures consisting of purified enzyme and $100 \mu 1$ of $0.05 \mathrm{M}$ acetate buffer at $\mathrm{pH} 6.5$ were incubated at various temperatures for $10 \mathrm{~min}$.

The activity of purified leucine aminopeptidase II at various temperature was determined with Leu-Gly-Gly and Leu- $\beta$-naphthylamide for $10 \mathrm{~min}$ incubation. The enzyme was found to be most active at $50^{\circ} \mathrm{C}$ (Fig. 8). Heat stability tests showed that the enzyme 
was stable up to $60^{\circ} \mathrm{C}$, but lost its activity almost completely at $70^{\circ} \mathrm{C}$ for $10 \mathrm{~min}$. Calcium ions showed some protective effect on the enzyme activity toward Leu-Gly-Gly from heat denaturation. Thermo-activation was studied at various temperatures for $10 \mathrm{~min}$. Heating leucine aminopeptidase II at 40,50 and $60^{\circ} \mathrm{C}$ for $10 \mathrm{~min}$ in the presence of $10^{-2} \mathrm{M}$ $\mathrm{CoSO}_{4}$ caused the increase of arylamidase activity. Thermo-activation was not observed for peptidase activity with Leu-Gly-Gly (Fig. 9).

\section{Table III. Effect of Various Metal Salts} ON LEUCINE AMINOPEPTIDASE II

Reaction mixtures were $1 \mathrm{ml}$ of $0.05 \mathrm{M}$ Tris- $\mathrm{HCl}$ buffer containing of the purified enzyme, substrate and varing concentrations of metal salts at $\mathrm{pH} 8.0$. After $10 \mathrm{~min}$ reaction at $30^{\circ} \mathrm{C}$, the amino acid or naphthylamine liberated was measured by the method described in the text.

\begin{tabular}{lcc}
\hline \multicolumn{2}{c}{$\begin{array}{c}\text { Metal salts added, } \\
10^{-3} \mathrm{M}\end{array}$} & \multicolumn{2}{c}{ Relative activity $(\%)$} \\
Leu-Gly-Gly & Leu- $\beta-\mathrm{NA}$ \\
\hline $\mathrm{None}$ & 100 & 100 \\
$\mathrm{CoSO}_{4}$ & 115.0 & 172.5 \\
$\mathrm{MnCl}_{2}$ & 108.0 & 113.7 \\
$\mathrm{NiSO}_{4}$ & 86.2 & 85.5 \\
$\mathrm{ZnSO}_{4}$ & 97.0 & 70.8 \\
$\mathrm{MgSO}_{4}$ & 113.2 & 111.2 \\
$\mathrm{CaCl}_{2}$ & 118.6 & 111.1 \\
$\mathrm{~Pb}_{\left(\mathrm{CH}_{3} \mathrm{COO}\right)_{2}}$ & 0 & 6.8 \\
$\mathrm{CuSO}_{4}$ & 0 & 5.7 \\
$\mathrm{HgCl}_{2}$ & 42.6 & 19.0 \\
\hline
\end{tabular}

* $4 \times 10^{-3} \mathrm{M}$
Effect of metal ions on the enzyme activity

As shown in Table III, remarkable inhibition of the enzyme action was shown by $\mathrm{Pb}^{2+}$, $\mathrm{Cu}^{2+}$ and $\mathrm{Hg}^{2+}$ ions. $\mathrm{Co}^{2+}, \mathrm{Mn}^{2+}, \mathrm{Mg}^{2+}$ and $\mathrm{Ca}^{2+}$ ions activated the enzyme.

Effect of various reagents on the enzyme activity

Table IV shows the effect of various reagents. on the enzyme activity which are known to inactivate proteases of various origins. The enzyme was inhibited by metal chelating agents such as EDTA, $\alpha, \alpha^{\prime}$-dipyridyl and 0 phenanthroline and $\mathrm{S}-\mathrm{S}$ dissociating agents like $\beta$-mercaptoethanol and sodium thioglycolate. Specific sulfhydryl reagents like $p$ chloromercuribenzoate and monoiodoacetate did not show any inhibitory effect on the peptidase activity.

\section{Hydrolysis of some peptides}

Two-tenth $\mathrm{ml}$ of enzyme solution $(69.6 \mu \mathrm{g}$ protein) in $0.1 \mathrm{M}$ acetate buffer (pH 6.5) was added to $1 \mathrm{mg}$ of Leu-Gly-Glu (kindly supplied by Dr. S. Sakakibara), Pro-Leu-Gly-Gln, Gly-Pro-Leu-Gly-Gin and angiotensin I (supplied by Protein Research Foundation, Osaka, Japan). After incubation for appropriate period at $30^{\circ} \mathrm{C}, 10 \mu \mathrm{l}$ aliquots of the reaction mixture were spotted on a thin layer of Kieselgel G (E. Merk AG. Darmstadt) and developed at $25^{\circ} \mathrm{C}$ for $3 \mathrm{hr}$ by the ascending method using a mixture of $n$-butanol, acetic

Table IV. Effect of Various Reagents on the Leucine Aminopeptidase II

Mixtures of the purified enzyme and substances indicated were incubated in $0.05 \mathrm{M}$ acetate buffer (pH 6.5) for $20 \mathrm{~min}$ at $30^{\circ} \mathrm{C}$. After this period, activities were assayed and compared with a control.

\begin{tabular}{lccc}
\multicolumn{1}{c}{ Inhibitor } & Concentration & \multicolumn{2}{c}{ Remaining activity $(\%)$} \\
Leu-Gly-Gly & Leu- $\beta$-NA \\
\hline None & & 100 & 100 \\
EDTA & $4 \times 10^{-3}$ & 51.8 & 57.8 \\
$\alpha, \alpha$-Dipyridyl & $4 \times 10^{-3}$ & 0.3 & 3.4 \\
o-Phenanthroline & $4 \times 10^{-3}$ & 0 & 0 \\
$p$-Chloromercuribenzoate & $10^{-3}$ & 114.1 & 94.0 \\
Monoiodoacetate & $4 \times 10^{-3}$ & 125.7 & 103.2 \\
$\beta$-Mercaptoethanol & $4 \times 10^{-3}$ & 0 & 0 \\
Sodium thioglycolate & $4 \times 10^{-3}$ & 0 & 0.3 \\
Sodium hexametaphosphate & $4 \times 10^{-3}$ & 82.7 & 92.0 \\
L-Cysteine & $4 \times 10^{-3}$ & & 93.6 \\
DFP & $10^{-2}$ & 75.5 & 28.6 \\
DFP & $10^{-3}$ & 78.5 & 9.4 \\
\hline
\end{tabular}




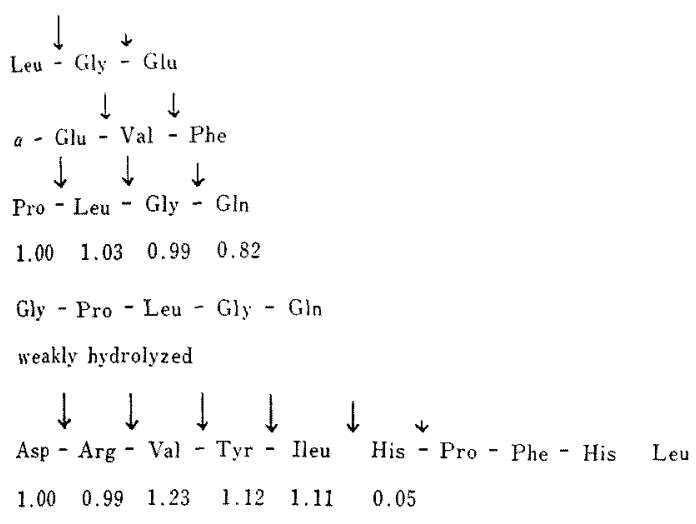

FIG. 10. Actions of Leucine Aminopeptidase II on Various Peptides.

The enzymatic hydrolysis of the peptides was made in $0.1 \mathrm{M}$ acetate buffer ( $\mathrm{pH} 6.5$ ) for $24 \mathrm{hr}$ at $30^{\circ} \mathrm{C}$. The numerical figures indicate the relative quantity of liberated amino acids. Arrow marks indicate the peptide bonds split by the enzyme.

acid and water $(4: 1: 1)$ as the solvent. The thin layer was then dried and detection of separated components was carried out by spraying of $0.25 \%$ solution of ninhydrin dissolved in ethanol. After $24 \mathrm{hr}$ incubation, amino acids in the reaction mixtures were determined with a Hitachi model 034 liquid chromatograph by the two column system (Hitachi custom ion-exchange resin 2611 and 2612 columns of $0.6 \times 10 \mathrm{~cm}$ and $0.9 \times 50 \mathrm{~cm}$ ) according to the procedure of Moore et al. ${ }^{9}$ Based on the results summarized in Fig. 10 the enzyme was found to hydrolyze the peptide liberating amino terminal amino acid and was confirmed to be aminopeptidase.

\section{Effect of $\mathrm{NaCl}$ on the enzyme activity}

As shown in Fig. 11, $\mathrm{NaCl}$ at high concentration $(18 \%)$ reduced the enzyme activity about $90 \%$ for Leu-Gly-Gly, about $75 \%$ for $\alpha$-Glu-Try-Glu, about $70 \%$ for $\alpha$-Glu-Try and about $25 \%$ for Met-Glu, respectively.

\section{DISCUSSION}

The aminopeptidase II from Asp. oryzae 460 showed different behavior on optimum pH (Fig. 6), thermo-acitivation (Fig. 9) and effect of $\mathrm{NaCl}$ (Fig. 11) for various substrates.

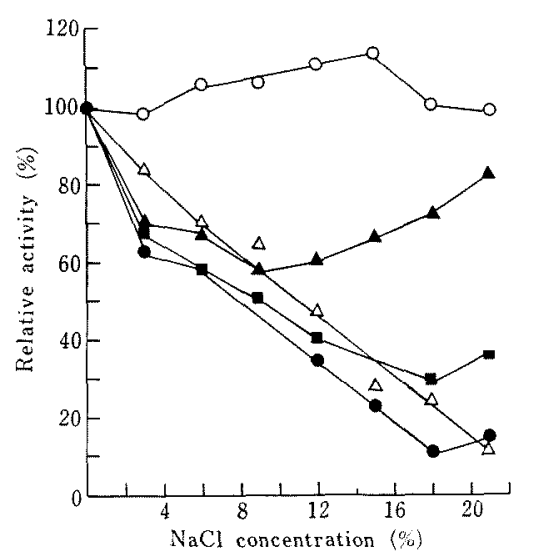

Frg. 11. Effect of $\mathrm{NaCl}$ on Leucine Aminopeptidase II.

- Leu-Gly-Gly in $0.05 \mathrm{M}$ phosphate buffer at pH 8.0; $0-0$, Leu- $\beta$-NA in $0.05 \mathrm{M}$ Tris-HCl buffer at $\mathrm{pH} 8.0 ; \Delta-\triangle, \alpha$-Glu-Try-Glu in $0.05 \mathrm{~m}$ acetate buffer at pH $5.0 ; \Delta-\Delta$ Met-Glu in $0.05 \mathrm{M}$ acetate buffer at $\mathrm{pH} 5.0 ; \mathbf{-}-\alpha$, $\alpha$-Glu-Try in $0.05 \mathrm{M}$ acetate buffer at $\mathrm{pH}$ 5.0. The incubation mixtures consisting of $50 \mu$ of purified enzyme $(17.4 \mu \mathrm{g}), 0.7 \mathrm{ml}$ of varying concentration of $\mathrm{NaCl}$ and $0.25 \mathrm{ml}$ of $10^{-3} \mathrm{M}$ substrate were incubated at $30^{\circ} \mathrm{C}$.

Such phenomena were frequently observed in other enzymes. For example, aminopeptidase of Bac. stearothermophilus ${ }^{10}$ and brain arylamidase $^{11}$ exhibited two different $\mathrm{pH}$ optima depending on substrates. Dissimilar patterns of inhibitory effects on the former enzyme by $8 \mathrm{M}$ urea and of stimulatory or inhibitory effects on the latter enzyme by a variety of metal ions were also found for different substrates. Similar results for leucine aminopeptidase I from Asp. oryzae 460 was reported in the previous paper. ${ }^{6}$

Thermo-activation in the presence of $\mathrm{Co}^{2+}$ ions is also characteristic of Asp. oryzae leucine aminopeptidase II. Similar phenomenon was reported for the thermophilic aminopeptidase from Bac. stearothermophilus ${ }^{12}$, and the leucine aminopeptidase I from $A s p$. oryzae. ${ }^{\mathrm{B}}$

Mammalian tissues contain aminopeptidases or arylamidases with a great variety of substrate specificity. Enzymes have been isolated that preferentially hydrolyze peptide bonds involving $\mathrm{N}$-terminal acidic amino acids (glutamate or aspartate), ${ }^{13,14)}$ basic amino acids 
(lysine or arginine) ${ }^{15,16)}$ alanine, ${ }^{17,18,19)}$ methionine, ${ }^{20,21)}$ glycine, ${ }^{11)}$ cystine, ${ }^{22)} \beta$-aspartate, ${ }^{23)}$ or pyrrolidone carboxylate. ${ }^{24)}$ Since the aminopeptidase II from Asp. oryzae preferentially hydrolyzed the oligopeptides that possess leucine as the $\mathrm{N}$-terminal amino acid, the present aminopeptidase was named leucine aminopeptidase II.

The leucine aminopeptidase II from Asp. oryzae was not inhibited by $\mathrm{SH}$ reagents as the aminopeptidase and dipeptidase from Asp. oryzae. ${ }^{25)}$ But the aminopeptidase B from rat liver, ${ }^{15)}$ arylamidases in regenerating wound tissue of a rat $^{21)}$ and the brain arylamidase from the soluble fraction of bovine brain $^{11)}$ were inhibited by $\mathrm{SH}$ reagents. This enzyme was inhibited by $\mathrm{S}-\mathrm{S}$ dissociating agents like the aminopeptidase B from rat liver. ${ }^{15}$ )

Leucine aminopeptidase II was shown to be similar in molecular weight, optimum $\mathrm{pH}$ and substrates hydrolyzed to aminopeptidase from Asp. oryzae ${ }^{26)}$ reported by Lehmann and Uhlig. Leucine aminopeptidase II was shown to be dissimilar in molecular weight, substrate specificity, optimum temperature and heat stability to leucine aminopeptidase $\mathrm{I}^{6}$ ) from Asp. oryzae 460.

Acknowledgements. The authors wish to thank Profs. T. Asai, K. Arima and Y. Ikeda for their kind guidance. The authors are grateful to Miss M. Yamazaki for her technical asisstance. They also wish to thank Dr. S. Sakakibara for his kind supply of peptides.

\section{REFERENCES}

1) T. Nakadai, S. Nasuno and N. Iguchi, Agr. Biol. Chem., 36, 261 (1972).

2) T. Nakadai, S. Nasuno and N. Iguchi, ibid., 36, 1239 (1972).

3) T. Nakadai, S. Nasuno and N. Iguchi, ibid., 36, 1343 (1972).

4) T. Nakadai, S. Nasuno and N. Iguchi, ibid., 36, 1473 (1972).
5) T. Nakadai, S. Nasuno and N. Iguchi, Agr. Biol. Chem., 36, 1481 (1972).

6) T. Nakadai, S. Nasuno and N. Iguchi, ibid., 37, 775 (1973).

7) S. Nasuno and T. Nakadai, J. Ferment. Technol., 49, 544 (1971).

8) T. Nakadai, S. Nasuno and N. Iguchi, Chomi Kagaku (Seasoning Science), 18, 435 (1971).

9) S. Moore, D. H. Spackman, and W. H. Stein, Anal. Chem., 30, 1185, 1190 (1958).

10) G. Roncari and H. Zuber, Int. J. Protein Research, I, 45 (1969).

11) A. S. Brecher and J. B. Suszkiw, Biochem. J,, 112, 335 (1969).

12) P. Moser G. Roncari and H. Zuber, Int. J. Protein Research, II, 191 (1970).

13) G. G. Glenner, P. J. McMillan and J. E. Folk, Nature, 194, 867 (1962).

14) I. Nagatsu, T. Nagatsu, T. Yamamoto, G. G. Glenner and J. E. Mehl, Biochim. Biophys. Acta, 198, 255 (1970).

15) V. K. Hopsu, K. K. Makinen and G. G. Glenner, Arch. Biochem. Biophys., 114, 557 (1966); idem, ibid., 114, 567 (1966).

16) K. K. Makinen and P. L. Makinen, Int. J. Protein Research, III, 41 (1971).

17) N. Rehfeld, J. E. Peters, H. Giesecke, L. Beier and R. J. Haschen, Acta Biol. Med. Ger., 19, 809 (1967).

18) F. J. Behal and G. H. Little, Clin. Chim. Acta, 21, 347 (1968).

19) F. J. Behal, G. H. Little and R. A. Klein, Biochim. Biophys. Acta, 178, 118 (1969).

20) F. J. Behal and M. N. Story, Arch, Biochem. Biophys., 131, 74 (1969).

21) P. L. Makinen and J. Raekallio, Acta Chem. Scand, 22, 597 (1968).

22) I. Sjoholm, FEBS Letters, 4, 135 (1969).

23) F. E. Dorer, E. E. Haley and D. L. Buchanan, Arch. Biochem. Biophys., 127, 490 (1968).

24) R. W. Armentrout, Biochim. Biophys. Acta, 191, 756 (1963).

25) T. Akatsuka and M. Sato, Bull. Agr. Chem. Soc. Japan, 27, 71 (1963).

26) H. Lehmann and H. Uhlig, Hoppe-Seyler's $Z$. Physiol. Chem., 350, 99 (1969).

27) J. A. Goldbarg and A. M. Rutenburg, Cancer, 11, 283 (1958).

28) B. J. Davis, Ann. N. Y. Acad. Sci., 121, 404 (1964). 